\title{
$8 \mathrm{M} / \mathrm{C}$ アクデフロー・ベルフォームの操業経験
}

\author{
紀州製紙侏紀州工場製紙部 綱 切 英 夫
}

\section{Operating Experience of Acdeflo and Bel Form on Paper Machine No. 8}

\author{
Hideo Tsunakiri \\ Kishu Mill, Kishu Paper Co., Ltd.
}

The paper machine No. 8 of Kishu Mill started up from March 1989 and has been operating successfully.

This report is described on the operating experience of Acdeflo and Bel Form from start to now.

\section{1.はじめに}

紀州工場 8 号マシンは三菱重工業侏三原製作所によ るコンプリートマシンで, 昭和 63 年 3 月の起工式から 1 年かけて完成し予定通りのスケジュールで平成元年 3 月に稼動した。

当社においては, 昭和 55 年紀州工場 7 号マシンを設 置して以来 8 年ぶりで，ユーザーニーズが厳しくなっ てきている状況に対応し得る製品を目指した最新鋭の マシンである。

紀州工場では純白ロール紙・色上質紙・上質紙・唒 クラフト紙・情報関連用紙を抄造しており，8号マシ ンは色上質紙の専抄マシンである。

アクデフロー・ベルフォームを選定した理由につい
ては,

(1) 米坪 50 ～ $160 \mathrm{~g} / \mathrm{m}^{2}$ と広範囲にわたって抄造す るため流量レンジが広く、どのレンジにおいても プロファイル，繊維配向性，地合等が満足されな ければならない。

(2) 先に昭和 61 年, 紀州工場 2 号マシンの改造の際 に設置したアクデフローが操業中における流量変 更・坪量プロファイル調整が容易な点, 及びメー カーのパイロットマシンでのテスト実施，これら からほほ満足すべき結果が期待できると判断し， 三菱アクデフロー，ワイヤパートはベルフォーム （タイプII）を採用した。

その後, 平成 3 年 7 月には 6 号マシンについても更 に改良の進んだアクデフロー (IIIM) ベルフォーム (夕

表 1 ヘッドボックス仕様

\begin{tabular}{|c|c|c|}
\hline & 8 号マシン & 6 号 マシン \\
\hline メ - 力 - & 三菱重工業(株) & 左 \\
\hline ヘッドボックス形式 & アクデフローIII & アクデフローIIIM \\
\hline スライスボンド幅 & $3,750 \mathrm{~mm}$ & $3,700 \mathrm{~mm}$ \\
\hline 設 計 流 量 & $40.5 \mathrm{~m}^{3} / \mathrm{min}$ & $33.7 \mathrm{~m}^{3} / \mathrm{min}$ \\
\hline 設計最高速度 & $1,000 \mathrm{~m} / \mathrm{min}$ & $800 \mathrm{~m} / \mathrm{min}$ \\
\hline チャンネル数 & 4 チャンネル & 5 チャンネル \\
\hline チューブバンク & 2 段穴のフローチューブ & 左 \\
\hline フォーミングレングス & $9.5 \mathrm{~m}$ & $10.4 \mathrm{~m}$ \\
\hline
\end{tabular}

平成 4 年度年次大会（'92.11.11～13，紀伊勝浦）において発表した。 


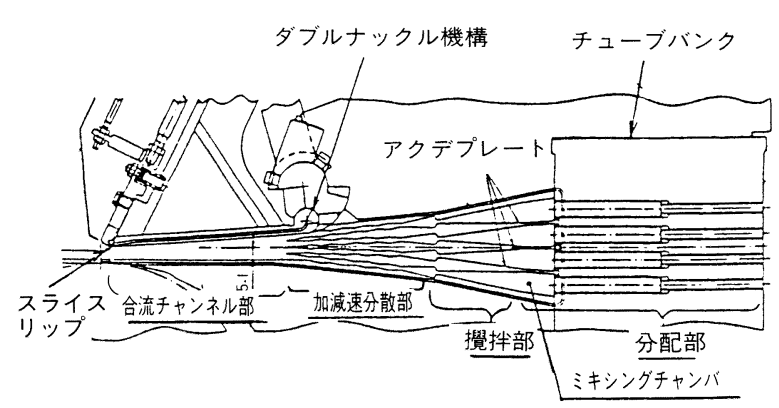

図 1 アクデフローボックス流路形状

イプIII）に改造した。

更に本年 7 月には 6 号マシンの結果をもとに 8 号マ シンも 6 号マシンと同形式のヘッドボックス, ベル フォームに改造した。

\section{2. ヘッドボックス}

\section{1 仕 様}

本機の最大の特徵であるアクデフロー部は, 従来の マイクロタービュランスによる繊維分散とは異なり, 独特の形状をもつ加減速流路でフロックは加圧・減圧 の作用を受け繊維を分散させる。

ダブルナックル機構により, スライスボディ及びス ライスリップを前後して水平移動させ，スライス ジェットの着地位置を調整する。

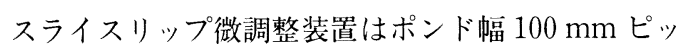
チで配置され, 熱膨張式プロファイル調整装置が BM 計に接続されてプロファイル調整する（図 1 )。

\section{2 スライスリップ微調整とプロファイル}

スライス開度はできる限り幅方向に一定して変形の

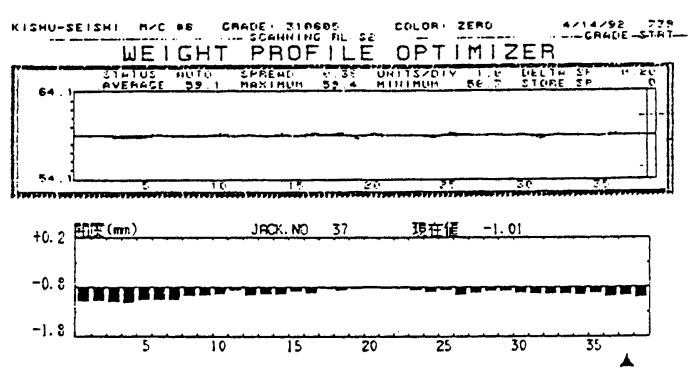

図 2 スライスリップ微調整と BDプロファイル

ない事が望ましいが，8号マシンでは両端がしまり気 味になっている。

しかし，この傾向が通常マシン外側に流れ出る原料 を抑えやすく，繊維配向性調整を有利とする（図2）。

\section{3 繊維配向性}

マシンで抄造されている紙には繊維配向性を重視す るものがあり，へッドボックスは繊維配向性を決定づ ける大きな役割を持つ。

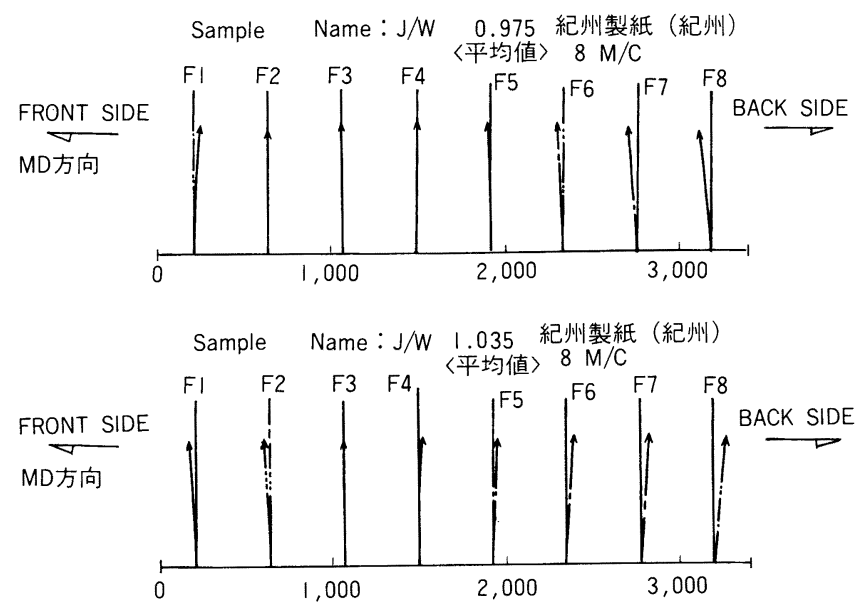

図 3 ジェットノワイヤ速度比と繊維配向角 
ここでは再循環流量・ブリード量共一定で，ジェッ トノワイヤ速度比のみ変更した場合の各部における $\mathrm{MD}$ 方向の繊維配向角の変化を示す。

なお，纎維配向角は Sonic Sheet Tester で測定して いる。

通常, 良好な地合のジェット/ワイヤ速度比は 1.01 であり，その值より小さい側（ドラッグ側）にすれば， 両耳部の繊維配向角はマシン中央側に向き，大きい側 (ラッシュ側)にすれば外側に向き再現性が良く，調整 の容易なへッドボックスである（図３）。

\section{4 ヘッドボックス内部の污れ}

当初, ヘッドボックス内部の污れを懸念して，8号 マシンアクデフローはマシン停止時のスライスリップ 開度を標準品より大きくできる方式にしたり，チュー ブバンク・アクデ部洗浄治具を製作したが，月 1 回の 苛性洗浄を行う事により污れの問題は発生していない。

\section{3. ワイヤパート}

\section{1 ベルフォームフォーマ ボトム}

脱水エレメントは 10 ブレードフォーミングボード 1 組, 4 ブレードのフォイルボックス 5 組, 9 ブレード のバキュームフォイルボックス 1 組, ワイヤサクショ ンボックス 2 組でスタートしたが，プレゾーンでの脱 水量不足の問題から, 後に 4 ブレードフォイルボック スを 6 ブレード式に 2 基変更し, 更にバキュームフォ イルボックスを新たに 1 基追加した。

\section{2 ベルフォームフォーマ トップ}

エレメント構成は 9 ブレードのフォーミングシュー 1 組, オートスライス 1 組, センターロールセイブオー ル 1 組, トランスファーサクションボックス 1 組から なる。

フォーミングシュー部の脱水圧力と遠心力により， 上方に脱水された白水はオートスライスに吸引され， またフォーミングシュー先端のかき落しによって下方 にも脱水される。

センターロール部の面圧により, 再度上方ならびに 下方へ脱水され, 上方の白水はセンターロールセイブ オールに吸引される。

ベルフォームの入口濃度は $1.0 \sim 1.5 \%$, 出口は $10 \%$ 程度である。上部脱水此率は $20 \%$ 前後で地合を見なが ら比率調整を行っている。

\section{3 ベルフォームガイドロール出側セイブオール}

\section{撤去}

当初 8 号マシンは, トランスファーサクションボッ クスが 1 基しかなく, トップワイヤへの微細纎維の持 ち回りで，粕がフレームやガイドロール出側セイブ
オール等に付着し，その後シートに落下して紙切れ発 生の問題が出た。

対策としてシャワー設備で対応したが，ガイドロー ル出側のセイブオールについては内部洗浄困難な事も あって撤去した。

トップシュー, 中間サクションボックス等の脱水エ レメントを追加した 6 号マシンベルフォームIIIにおい ては, トップワイヤへの微細纎維の持ち回わりが少な い。その結果を踏まえて本年 7 月に 8 号マシンも 6 号 マシンと同タイプのベルフォームIIIに改造した理由の 一つである。

\section{4. 品質}

\section{1 透過光变動法による地合比較}

地合はへッドボックスとワイヤパートの相乗効果に よって構成されるが, ここではべルフォーム部での上 部脱水比率を变更して透過光変動法により地合の比較 を行った。

8 号マシンベルフォームIIでは上部脱水比率を上げ てゆくほど若干ではあるが地合が落ちている。

これに対し 6 号マシンベルフォームIIIでは上部脱水 比率を増すほど地合が良い方向に向かっている。

地合指数で比較すると 8 号マシンは 4.8 5.0であ るのに対し，6号マシンは 4.3 4.4 と改善されている (図 4 )。

\section{2 紙層分割法による地合比較}

紙層の地合を分割比較するのに都合のよい透明テー プを用いた剥離法を採用した。但し，分割紙を調製出 来ると言っても，必ずしも 1 回分割で均等の坪量が得 られる訳ではなく，バラッキが発生しているが一応 8 分割に剥離した。

分割サンプルを見ると図 4 の透過光変動法による地 合指数と同様, 8 号マシンより 6 号マシンの方が良好 な結果となっている。特にフェルト面 1, 2 枚目で顕著 な差が出ている（図５）。

8 号マシンの上部脱水比率は $23 \%$ で, フェルト面 1

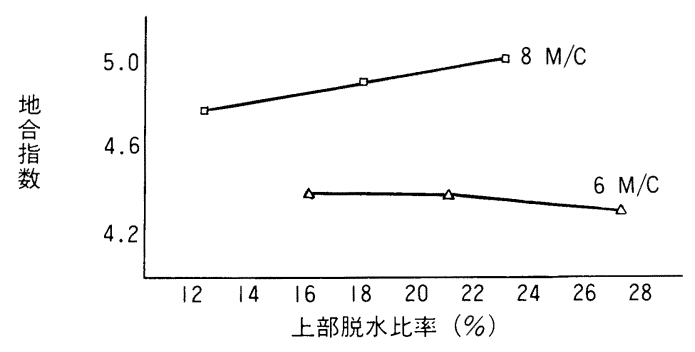

図 4 上部脱水比率と地合 (透過光变動法) 


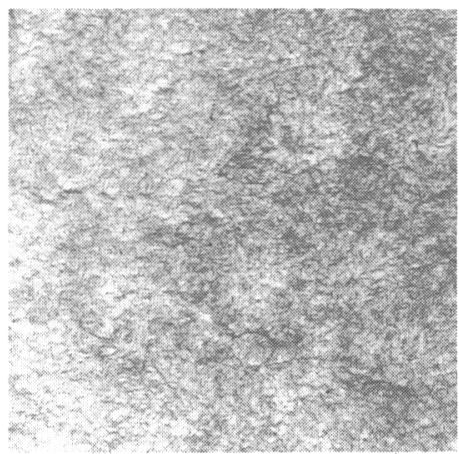

F面（1枚目）

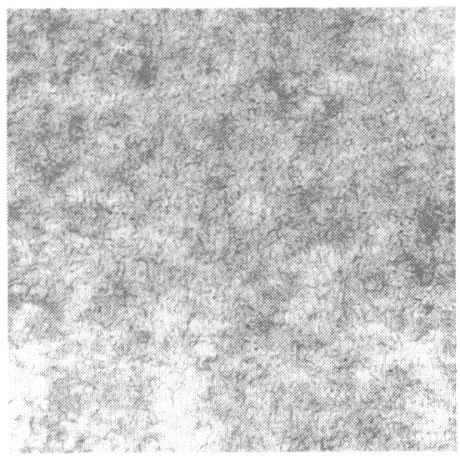

中央 ( 3 枚目)

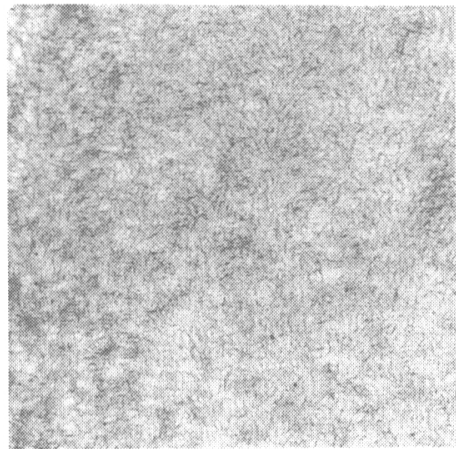

W面 ( 7 枚目)

8 号マシン

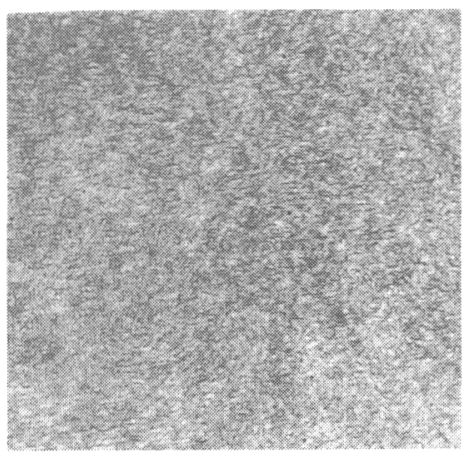

同 左

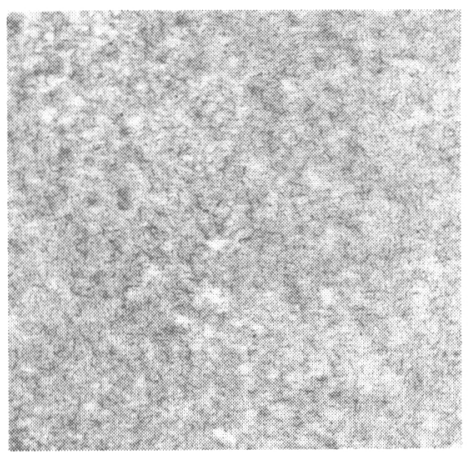

同 左

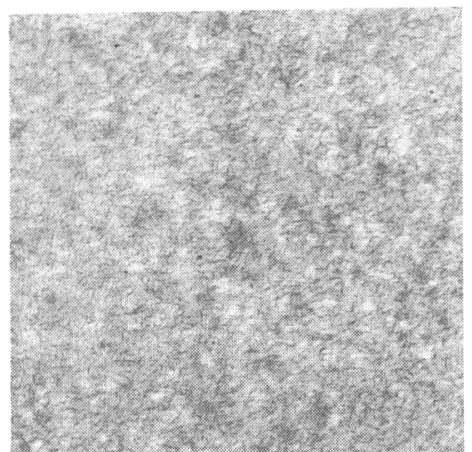

同左

6 号マシン

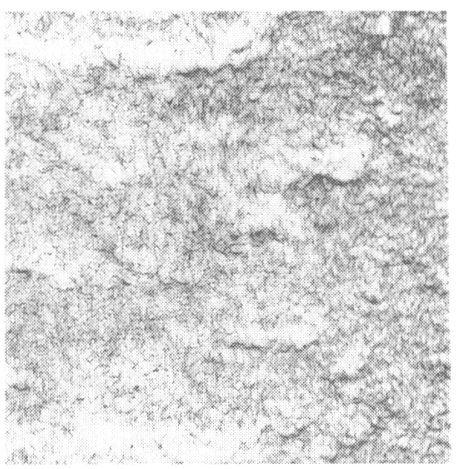

同 左

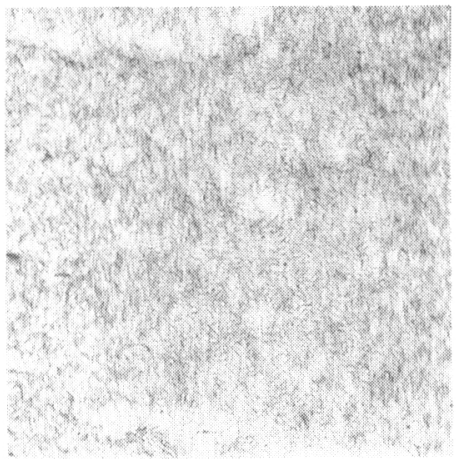

同 左

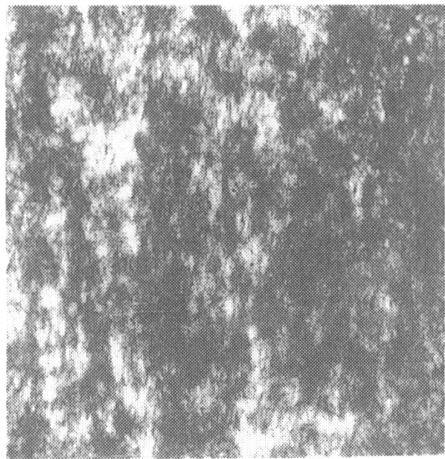

同左

8 号マシン

(クラッシング強調)

図 5 紙層分割法による地合比較

枚目にクラッシングの兆しが出ており地合を崩してい る。これが先程の地合指数に表われているものと考え られる。

クラッシングの原因はベルフォーム入口の水分率が ある限度以上になると，フォーミングシューの脱水， 及びオートスライスののみ込み量が限界を超えてし まって, センターロールでのクラッシングにつながる ものと思われる。
このクラッシングを強調して再現したのが図 5 で, サンプルは何れもフェルト面で強く繊維が $\mathrm{CD}$ 万向に 並んでいる。

これに対し 6 号マシンベルフォームIIIではセンター ロール前にトップシューュニットを設置している事に より, センターロール部での脱水負荷が減少し, 設置 後 1 年以上になるが末だ一度もクラッシングの発生は ない。 


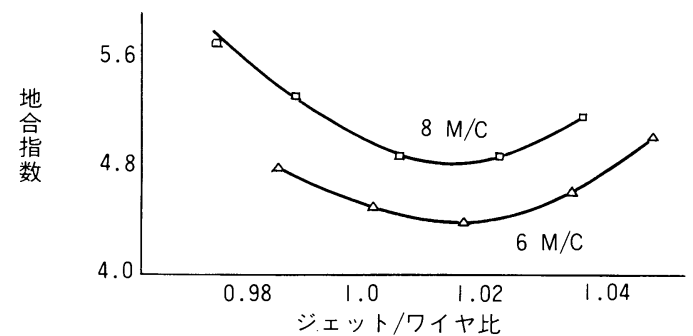

図 6 ジェット/ワイヤ比と地合

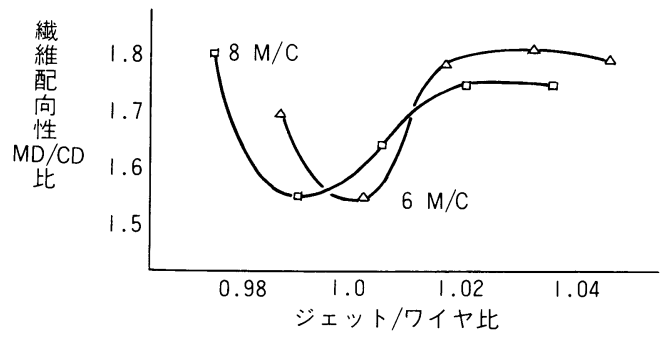

図 7 ジェット /ワイヤ比と纎維配向性(MD/CD比)

\section{3 ジェット/ワイヤ比と地合・繊維配向性}

(MD/CD 比)

ジェット／ワイヤ比と地合については図 6 に示す様 に 8 号マシンではジェット/ワイヤ比が 1.01 近辺が 良く, 繊維配向性 (MD/CD 比)については 0.99 の所 が最も小さい（図７）。

6 号マシンについては, ジェット/ワイヤ比 1.015, 繊維配向性 $\mathrm{MD} / \mathrm{CD}$ 比 1.002 が小さい。

\section{4 ベルフォーム上部脱水比変更による Ash} （紙厚方向）の変化

図 8 は 8 号マシンにおいてスライスリップ開度の変 更により，オートスライスの上部脱水比率を変更した もので, 上部脱水比率を增すほどトップワイヤ側の Ash が減少傾向になる。また, ボトムワイヤ側では逆

Ash

$(\%)$

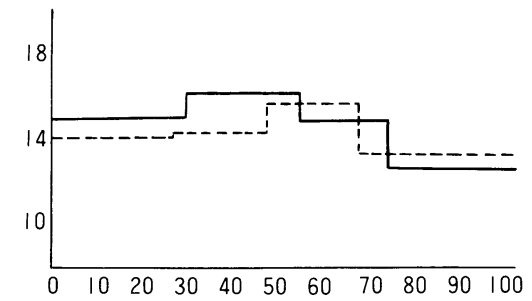

$$
\begin{aligned}
& \text { トップワイヤ側＼cjkstart紙厚方向坪量割合（\%） ホトムクイヤ側 } \\
& \text { 一オートスライスの脱水比 } 13 \% \\
& \text {-..- オートスライスの脱水比 } 23 \%
\end{aligned}
$$

図 $88 \mathrm{M} / \mathrm{C}$ オートスライスの脱水比率とAsh
Ash

$(\%)$

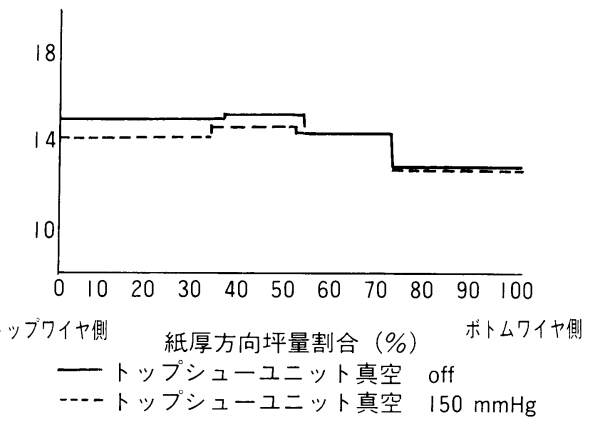

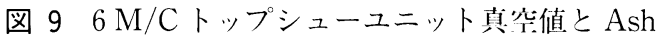

にAsh が増加している。

6 号マシンについては同一条件（リップ開度一定）

でトップシューュニットの真空值のみを変更した結果 であるがトップワイヤ側については 8 号マシンと同様 の結果となっている。なお，ボトムワイヤ側は殆ど変 化がない(図 9 )。

\section{5 ベルフォーム上部脱水比率変更による F 1 と W 1 の Ash • Fines $の$ 差}

図 10, 図 11 はオートスライスの脱水比率を変更し てシート 4 層分割によるトップワイヤ側：F 1, ボト ムワイヤ側：W 1 との Ash・Finesの差を示したもの である。

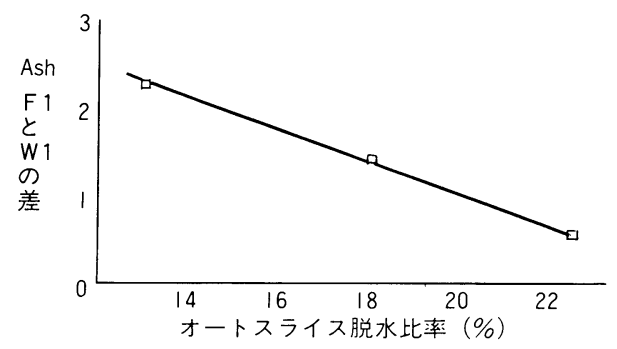

図 $108 \mathrm{M} / \mathrm{C}$ オートスライスの脱水比摔とAsh （4 層分割） F 1-W 1

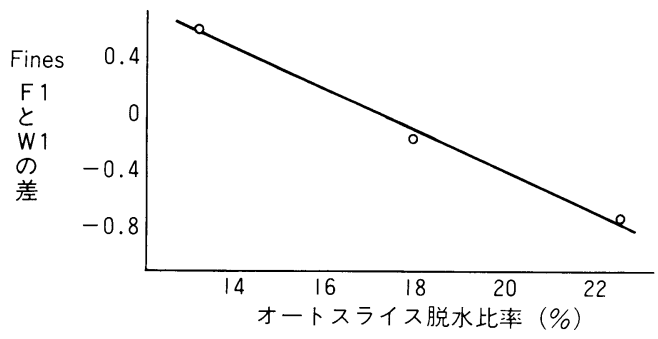

図 $118 \mathrm{M} / \mathrm{C}$ オートスライスの脱水比率と Fines （4 層分割） F 1-W 1 


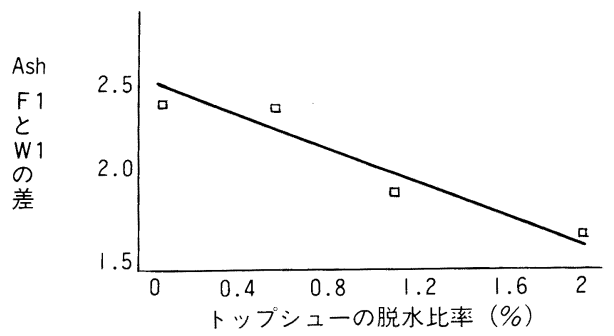

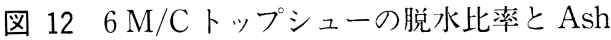
（4 層分割） F 1-W 1

脱水比率が增えるに従って Ash・Fines とも略減少 傾向にあり表裏差は改善されている。

図 12 は 6 号マシントップシューユニットの真空值 を変えて脱水比率を変更した場合であるが, Ash で約 $0.7 \% の$ 表裏差の改善が可能と言える。

しかし, Finesについては今一はつきりしない結果 となった（図 13）。

\section{おわりに}

時間的な制約もあり，今回は 8 号マシンのアクデフ ローヘッドボックス, 及びベルフォームフォーマーの

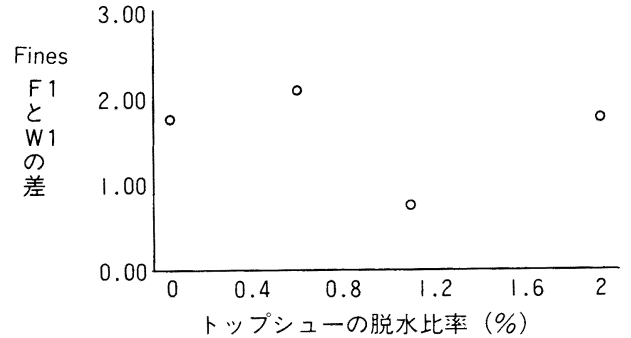

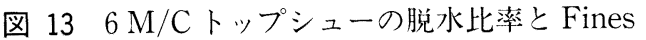
（4 層分割） F 1-W 1

操業経験と一部 6 号マシンとの比較も入れての発表に なりました。

今後は更に紙厚方向の Ash・Fines 分布を自在にコ ントロールできる操業技術の確立を目指して研究, 開 発を進め, 益々多様化かつ厳しさを増す品質要求に応 えるよう努力していく所存である。

最後に今回の発表に際し試料の測定等に御協力戴い た三菱重工業侏に感謝の意を表します。 